\title{
Variations in fatty acid methyl ester contents and composition in oil seeds Gundelia tournefortii L. (Asteraceae)
}

\begin{abstract}
Fatty acid methyl ester (FAME) extracts of Gundelia tournefortii L. (Asteraceae) belonging to the family Asteraceae, were prepared and their composition was analyzed by GC-MS. Among the fatty acids analyzed, the relative percentage of Linoleic acid methyl ester was high in oil seeds of G.tournefortii (43.98\%). The other extracts showed higher percentage Oleic acid methyl ester (28.29\%), Palmitic acid methyl ester $(13.42 \%)$ and 8 -Octadecenoic acid methyl ester $(6.89 \%)$.
\end{abstract}

Keywords: gundelia tournefortii, asteraceae, fatty acid esters, linoleic acid
Volume 6 Issue 6 - 2017

\author{
Sahar AA Malik Al-Saadi,'Karzan Omer \\ Qader, ${ }^{2}$ Tariq Omer Hassan ${ }^{3}$ \\ 'College of Science, Department of Biology, Basrah University, \\ Iraq \\ ${ }^{2}$ College of Science, Department of Biology, Sulaimani University, \\ Iraq \\ ${ }^{3}$ Bakrajo Technical Institute, Sulaimani, Iraq
}

Correspondence: Sahar AA MalikAI-Saadi, College of Science,
Department of Biology, Basrah University, Iraq,
Email saharmalik20I0@gmail.com,
karzanqader20I6@gmail.com

\section{Introduction}

Gundelia tournefortii L., is a medicinal plant belongs to the Asteraceae (Compositae) family, which grown in the Asian temperate zones of Western Asia ${ }^{1}$ it is found in the semi-desert areas of Lebanon, Egypt, Syria, Palestine, Jordan, Iraq, Iran, Azerbaijan, Turkmenistan, Armenia, and Turkey. ${ }^{2,3}$ Gundelia tournefortii is common name of tumbleweed, akub (kuub or aqub) and kanger in English, Arabic and Kurdish respectively. ${ }^{4}$ One species of Gundelia recorded in flora of Iranica Gundelia tournefortii, ${ }^{5}$ as well as in flora of Turkey only $G$. tournefortii recorded, but his flowers are giving different color as "green, yellow, white, maroon or red", it was glabrous or arachnoid. While in Armenia G. rosea is given as a synonym of G. tournefortii. ${ }^{7}$ But recently two new taxa well defined localities of Gundelia namely G. aragatsi and G. aragatsi. ${ }^{8}$ The plant is grown well in different localities, It is not able to grow in shade, but prefers sandy and loamy or acid, neutral and alkaline, drained and moist soils. ${ }^{9}$

In Current decade, many researchers have studies Gundelia tournefortii L. especially chemical components and pharmacological properties such as., ${ }^{40-18}$ All parts of $G$. tournefortii are used in medicinal plant for 2000 years, it is traditionally used for treatment of liver diseases, chest pain, diabetes, angina pectoris, vitiligo, stroke, gastric ailments, hypoglycemic, Laxative, sedative, diarrhea and bronchitis, skin diseases, pain, diarrhea, respiratory diseases, digestive disorders, high blood pressure and cancer., ${ }^{419-22}$ The Compounds found in Gundelia may be proved to have several pharmacological effects, it is reported to have anti-parasite antibacterial, anti-inflammatory, hepatoprotective, antioxidant, antiseptic and emetic effects and hypolipemic activities blood purifier. ${ }^{2,15,20}$ The stems and leaves of Gundelia tournefortii are used as food ingredients in soups and salads. $^{23}$

In several of studies chemical compositions were identified and the amount of the yields specially oils or volatile oil studied by
Jamshidzadeh et al. ${ }^{24}$ and reported that the major components of the of $\mathrm{G}$. tournefortii was $\alpha$-terpinyl acetate $(36.21 \%)$, methyl eugenol $(12.57 \%)$, eugenol (6.7\%), $\beta$-Caryophellene (5.94\%), and zingiberene $(5.84 \%)$. Fatty acids were varied between the part of plant, flower bud contains linoleic $(57.8 \%)$, oleic $(28.5 \%)$, palmitic $(8.1 \%)$, stearic, vacsenic and arachidic acids. Abdul et al. (2012) reported that the fatty acid composition of the seed oil of Gundelia L. contain myristic, palmitic, palmitolic, heptadecanoic, stearic, oleic, linoleic, and linolenic. high level of seed's oil recorded in oleic and linoleic acids contents of oil were $27.99 \%$ and $54.59 \%$, respectively. ${ }^{25}$ The total content of vitamin E was $51.9 \mathrm{mg} / 100 \mathrm{~g} .{ }^{12}$ Caffeic acid and caffeic acid derivatives, neochlorogenic acid, cryptochlorogenic acid, and chlorogenic acid isolated by Matthaus. ${ }^{4}$ While Farhang et al. ${ }^{22}$ relived that major components were palmitic acid $(12.48 \%)$, lauric acid (10.59\%), alpha ionene (6.68\%), myristic acid (4.45\%), 1-hexadecanol, 2-methyl (3.61\%), phytol (3.6\%), and beta turmerone (3.4\%). Gundelia tournefortii contains sterol; it was $3.7666 \mathrm{~g} /$ $\mathrm{kg}$ which included $\beta$-sitosterol (51.76\%), stigmasterol (18.52\%), 5-avenasterol (9.82\%), campesterol (6.02\%), 7-stigmastenol (3.68\%) and 7 -avenasterol $(2.63 \%)$. From aerial parts, isolated scopoletin, isoscopoletin, esculin, and a mixture of $\beta$-sitosterol and stigmasterol components. $^{3}$

\section{Materials and methods}

\section{Plant material}

Gundelia tournefortii L. seeds were collected from North region of Iraq and dried in a standard situation without light. For extraction $150 \mathrm{~g}$ of the powdered leaf material was taken. The powdered material was transferred into $250 \mathrm{ml}$ quick fit flask and extracted in the soxhlet extractor for 48 hours by using organic solvents hexane $500 \mathrm{ml}$. The extracts were filtered over Whatman No. 1 filter paper, and the filtrates were concentrated under reduced pressure to pasty mass for further studies. 


\section{Gas chromatography-MS analysis}

\section{GC-MS analysis}

GC-MS analysis was performed in University of Basrah, College of Agriculture, Iraq. GC-MS analysis was performed by using Shimadzu GC-QP 2010 Ultra gas chromatograph, The GC oven temperature was programmed from $40^{\circ} \mathrm{C}$ to $280^{\circ} \mathrm{C}$ at a rate of $15^{\circ} \mathrm{C} / \mathrm{min}$. Helium was used as carrier gas; inlet pressure was $96.1 \mathrm{kPa}$; linear velocity was
$47.2 \mathrm{~cm} / \mathrm{sec}$. Column flow was $1.71 \mathrm{~mL} / \mathrm{min}$, Injector temperature: $280^{\circ} \mathrm{C}$; injection mode: split. MS scan conditions: source temperature, $200^{\circ} \mathrm{C}$; interface temperature, $280^{\circ} \mathrm{C}$; Detector Gain, $0.69 \mathrm{kV}+0.10$ $\mathrm{kV}$; Scan speed, 1666. Start $50 \mathrm{~m} / \mathrm{z}$, End $800 \mathrm{~m} / \mathrm{z}$. The components of the Gundelia tournefortii fatty oil were identified by comparing the spectra with those of known compounds stored in the NIST library (2005) (Figure 1-10).

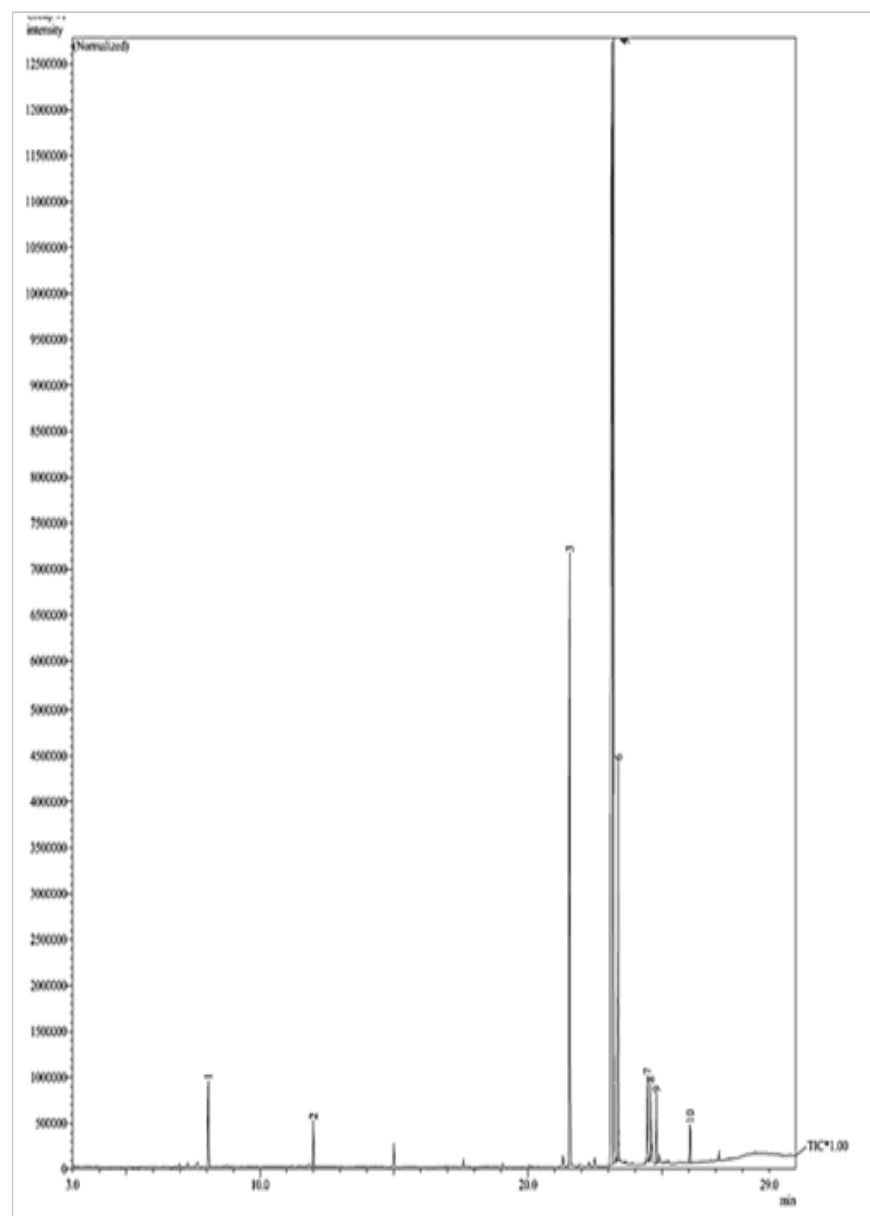

Figure I Chromatogram of fatty acid of Gundelia tournefortii L. seeds.

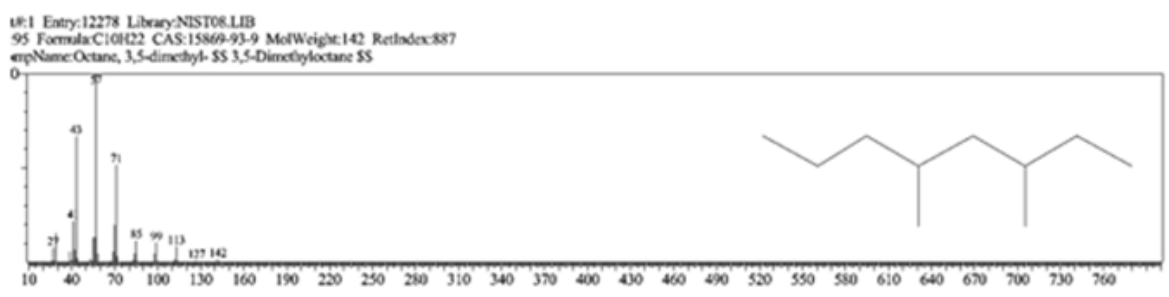

Figure $2 \mathrm{~A}$ typical gas chromatogram of the Octane,3,5-dimethyl.

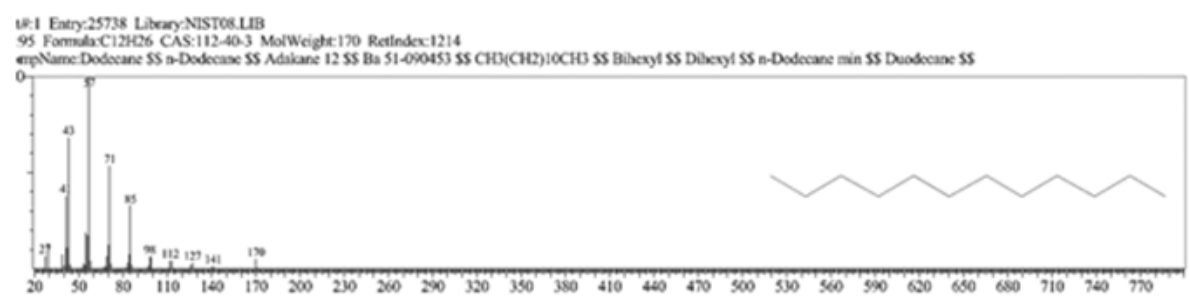

Figure $3 \mathrm{~A}$ typical gas chromatogram of the Dodecane. 


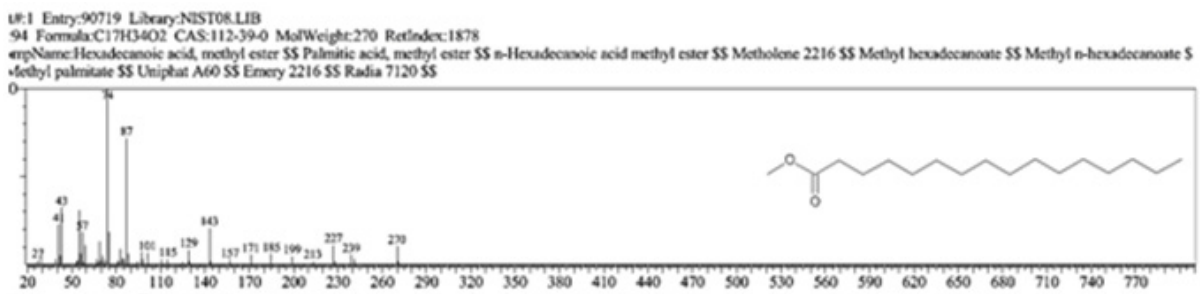

Figure $4 \mathrm{~A}$ typical gas chromatogram of the Hexadecanoic acid, methyl ester (Palmitic acid methyl ester).

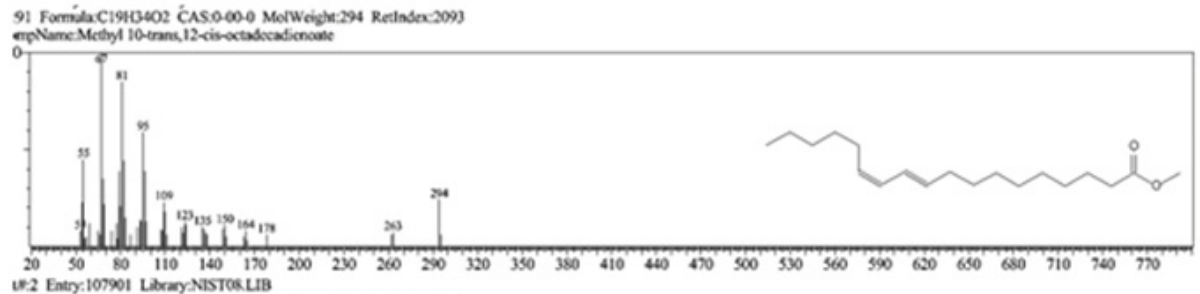

Figure 5 A typical gas chromatogram of the Methyl 10- trans, I2-cis-octadienoate.

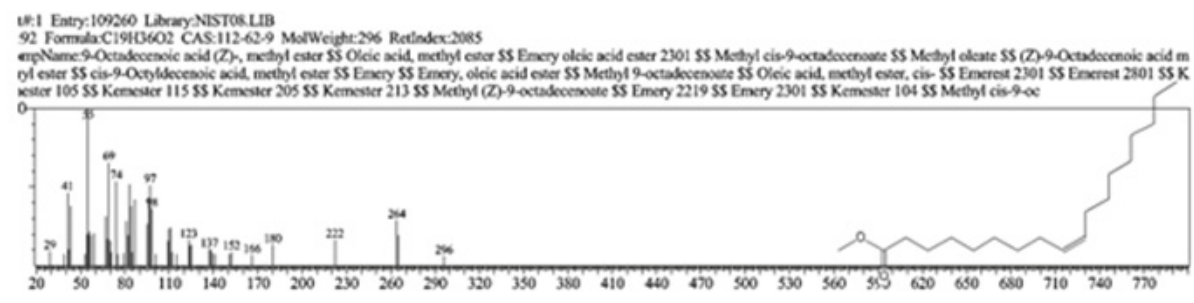

Figure $6 \mathrm{~A}$ typical gas chromatogram of the Oleic acid, methyl ester(or Emery oleic acid ester).

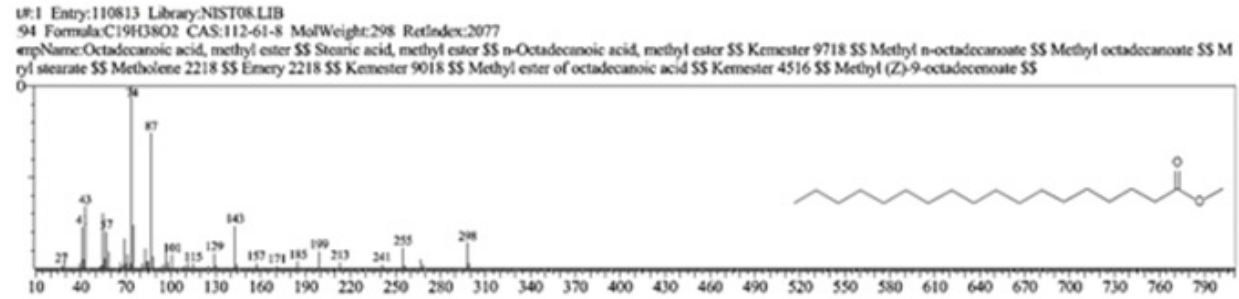

Figure 7 A typical gas chromatogram of the 8- Octadecanoic acid(Z)-methyl ester(or Stearic acid ester).

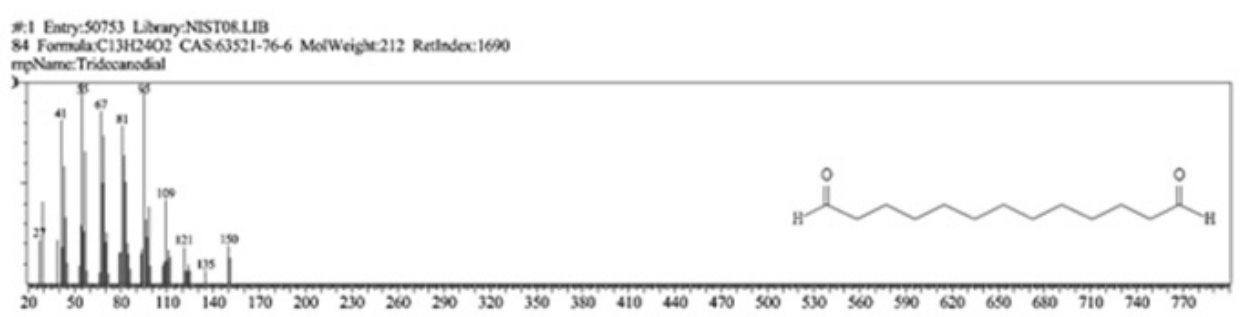

Figure 8 A typical gas chromatogram of the Tridecanedial.

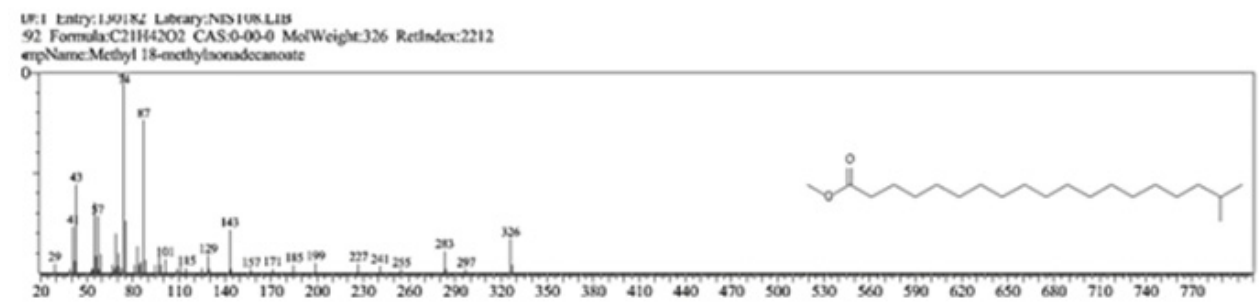

Figure 9 A typical gas chromatogram of the Methyl I8-methylnonadecanoate. 


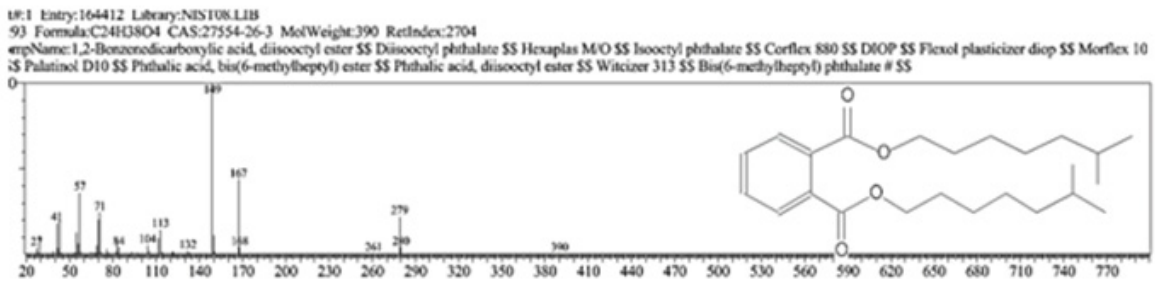

Figure $10 \mathrm{~A}$ typical gas chromatogram of the I,2-Benzendicarboxylic acid, diisooctyl ester.

\section{Results and discussion}

The GC-MS analysis of Gundelia tournefortii seed extract revealed the presence of 10 compounds (phytochemical constituents) (Figure 1) (Table 1) that could contribute to the medicinal property of the plant. The identification of the phytochemical compounds was confirmed based on the peak area, molecular formula and retention time. The active principles with their retention time (RT), molecular formula and peak area in percentage are presented in Table1.

Most of the chemical components identification of Gundelia tournefortii L. seeds represented fatty acid methyl ester, four components represented major contents in oil, the percentage of higher fatty acid were Linoleic acid methyl ester $43.98 \%$, Oleic acid methyl ester or (Emery oleic acid ester) were $28.29 \%$ and then Hexadecanoic acid methyl ester was $13.42 \%$. The components such as 9,12,15-Octadecatrienoic acid methyl ester (Table 1). Our results agree with $^{24,25}$ but not agree with ${ }^{22}$ The Phytochemical found in Gundelia tournefortii important as anti-inflammatory, hypocholesterolemic, cancer preventive, hepatoprotective, nematicide insectifuge, antihistaminic antieczemic, antiacne, antiandrogenic, antiarthritic, anticoronary and insectifuge properties. Previously, 9(Z),12(Z),15(Z)octadecatrienoic acid, methyl ester, also known as $\alpha$ - linolenic acid methyl ester known to inhibit proliferation of ER-positive and ERnegative breast cancer cells (Banua and Nagarajanb).

The plant Gundelia tournefortii rich with chemical groups including terpenes, hydrocarbons, alcohols, acids, esters and phenols, Farhang et al., ${ }^{22}$ recorded 70 compounds belonged to six main which were identified in Gundelia tournefortii. Our results not agree with him that the major components were palmitic acid (12.48\%)and then lauric acid $(10.59 \%)$, which may be occurred thus different the region, on the other hand, many researchers found two important factors, genetic and environmental factors, have the major effect on the genesis, formation, presence and absence of available constituents in the mentioned plant.

Because the high oil content of Gundelia seed (22.8\%), it is a potent source for extraction of edible oil. Ragasa et al. ${ }^{3}$ noticed that the fatty acid composition of this oil was similar to soybean and sunflower oils, while several of researchers found G. tournefortii a rich source of volatile oils, minerals and vitamins A, B and C, can be a good source of protein ${ }^{1,24}$ and $\mathrm{Ng}, 2015$ In addition, G. tournefortii had high potential for accumulating arsenic, perhaps very effective for removing contamination from soils Mallavadhani et al. ${ }^{4}$

Table I Compounds identified in the essential oil of Gundelia tournefortii L. seeds using gas chromatography mass spectrometry (GC-MS)

\begin{tabular}{|c|c|c|c|c|c|}
\hline Peak & Component & Area \% & Area & R.Time & M.F. \\
\hline 1 & Octane, 3,5-dimethyl & 1.93 & 2219210 & 8.073 & $\mathrm{C}_{10} \mathrm{H}_{22}$ \\
\hline 2 & Dodecane & 0.89 & 1020556 & 11.989 & $\mathrm{C}_{12} \mathrm{H}_{26}$ \\
\hline 3 & $\begin{array}{l}\text { Palmitic acid, methyl ester or (Hexadecanoic acid, methyl ester or } \\
\text { Methyl palmitate) }\end{array}$ & 13.42 & 15427572 & 21.558 & $\mathrm{C}_{17} \mathrm{H}_{34} \mathrm{O}_{2}$ \\
\hline 4 & Linoleic acid methyl ester; & 43.98 & 50556669 & 23.131 & $\mathrm{C}_{19} \mathrm{H}_{34} \mathrm{O}_{2}$ \\
\hline 5 & $\begin{array}{l}\text { Oleic acid, methyl ester or (9-Octadecenoic acid (Z), methyl ester } \\
\text { Emery oleic acid ester) }\end{array}$ & 28.29 & 32520105 & 23.189 & $\mathrm{C}_{19} \mathrm{H}_{36} \mathrm{O}_{2}$ \\
\hline 6 & 8-Octadecanoic acid, methyl ester & 6.89 & 7922867 & 23.367 & $\mathrm{C}_{19} \mathrm{H}_{38} \mathrm{O}_{2}$ \\
\hline 7 & Tridecanedial & 1.47 & 1685526 & $24.46 I$ & $\mathrm{C}_{13} \mathrm{H}_{24} \mathrm{O}_{2}$ \\
\hline 8 & Oxiraneoctanoic acid, 3-octyl-, methyl ester, cis - & 1.13 & 1300995 & 24.576 & $\mathrm{C}_{18} \mathrm{H}_{34} \mathrm{O}_{3}$ \\
\hline 9 & Methyl I8-methylnonadecanoate & 1.21 & 1385226 & 24.798 & $\mathrm{C}_{12} \mathrm{H}_{42} \mathrm{O}_{2}$ \\
\hline 10 & I,2- Benzenedicarboxylic acid, diisooctyl ester & 0.79 & 912976 & 26.051 & $\mathrm{C}_{24} \mathrm{H}_{38} \mathrm{O}_{4}$ \\
\hline
\end{tabular}




\section{Conclusion}

Results from this study have shown that the fatty acid contains compounds with proven pharmacological effects. GC-MS analysis revealed that 10 different chemical components were identified in the G. tournefortii. The high amounts of Linoleic acid methyl ester (43.98\%). Type of GC-MS analysis is the first step towards understanding the nature of active principles in this medicinal plant and will be helpful for further detailed study as well as gives a clear picture about the pharmaceutical value of that plant and their diversity and detailed photochemistry may add new knowledge to the information in the traditional medical systems. ${ }^{26,27}$

\section{Acknowledgements}

None.

\section{Conflict of interest}

The author declares no conflict of interest.

\section{References}

1. Ebrahimi A, Sani AM. Application of Gundelia tournefortii L. in yoghurt. J Appl Environ Biol Sci. 2015;4(12S):266-272.

2. Coruh N, Sagdicoglu Celep AG, Ozgokce F, et al. Antioxidant capacities of Gundelia tournefortii L. extracts and inhibition on glutathione -Stransferase activity. Food Chemistry. 2007;100:1249-1253.

3. Ragasa CY, Reyes MN, Carmen M, et al. Sterols and triterpenes from Gundelia tournefortii L. var Armata Der Pharma Chemica. 2016;8(20):240-243.

4. Matthaus B, Özcan MM. Chemical evaluation of flower bud and oils of tumbleweed (Gundelia tournefortii L.) as a new potential nutrition sources. J Food Biochem. 2011;35:1257-1266

5. Rechinger KH. Tribus Arctotidae Cass. In: Flora Iranica, et al. editors Akademische Druck Austria; 1989. p. 107-109.

6. Kupicha FK. Gundelia In: Flora of Turkey and the East Aegean Islands. Davis PH, et al. editors. Edinburgh: Edinburgh University Press; 1984;(5):325-326.

7. Avetisian VE. Gundelieae In Flora Armenii, et al. editors. 9Koeltz Scientific Books. Havlickuv Brod; 1995. p. 212-216.

8. Vitek E, Jarvis C. The typification of Gundelia tournefortii L. (Compositae). Ann Naturhist Mus Wien. 2007;108B:267-272.

9. Samani MA, Rafieian-Kopaei M, Gundelia NA. A systematic review of medicinal and molecular perspective. Pakistan Journal of Biological Sciences. 2013;16(21):1238-1247.

10. Erciyes AT, Karaosmanoglo F, Civelekoglu H. Fruit oils of four plan species of Turkish origin. Journal of American Oil Chemists Society. 1989;66(10):1459-1464.

11. Aburjai T, Darwish M, Al-Khalil S, et al. Screening of antibiotic resistance inhibitors from local plant materials against two different strains of Pseudomonas aeruginosa. J Ethnopharmacol. 2001;76(1):39-44.
12. Halabi S, Battah AA, Aburjai T, et al. Phytochemical and antiplatelet investigation of Gundelia tournifortii. Pharmceutical Biolology. $2005 ; 4: 496-500$

13. Karabulut A, Ozkan CO, Kamalak A, et al. Comparison of the nutritive value of a native Turkish forage, Jumbleweed hay (Gundelia tourneforii L.) wheat straw and alfalfa hay using in situ and in vitromeasurements with sheep. Arch Latinoam Prod Anim. 2006;14:78-83.

14. Darwish RM, Aburjai TA. Effect of ethnomedicinal plants used in folklore medicine in Jordan as antibiotic resistant inhibitors on Escherichia coli. BMC Complement Altern Med. 2010;10(10):9-10.

15. Haghi G, Hatami A, Arshi R. Distribution of caffeic acid derivatives in Gundelia tournifortii L. Food Chemistry. 2011;124:1029-1035.

16. Namama SH, Dalia AA, Hamid GH. Characteristics of fatty acid content in Gundelia L. Oil extract Iraqi Natural Journal of Chemistry. 2012;45:144-148.

17. Fathalivand A, Sarghein HS, Jamei R. Biochemical study of some populations of Gundelia tournefortii L. in West Azarbaijan. Iranian Journal of Plant Physiology. 2012;2(3)

18. Tabibian M, Nasri S, Kerishchi P, et al. The Effect of Gundelia Tournefortii Hydro-Alcoholic extract on sperm motility and testosterone serum concentration in mice. Zahedan J Res Med Sci. 2013

19. Jamishdzadeh A, Fereidoni F, Salehi Z, et al. Hepatoprotective activity of Gundelia tourenfortii. L. Journal of ethnopharmacology. 2005;101:233237.

20. Oryan S, Nasri S, Amin GR, Kazemi-Mohammady SMM, et al. Anti nociceptiveand anti-inflammatory effects of aerial parts of Gundeila tournefortii L. on NMRI male mice. J Shahrekord Univ Med Sci. $2011 ; 12: 8-15$.

21. Mosaddegh MF, Naghibi MF, Moazzeni H, et al. Ethnobotanical survey of herbal remedies traditionally used in kohghiluyeh va boyer ahmad province of iran. J Ethnopharmacol. 2012;141(1):80-95.

22. Farhang HR, Vahabi MR, Allafchian AR. Chemical compositions of the essential oil of Gundelia tournefortii L. (Asteraceae) from central Zagros, Iran. Journal of Herbal Drugs. 2016;6(4):227-233.

23. Ertug F. An ethnobotanical study in Central Anatolia (Turkey). Economic Botany. 2000;54:155-182.

24. Jamshidzadeh A, Fereidoona F, Niknahad H, et al. Hepatoprotective activity of Gundelia tourenfortii. Ethnopharmacol. 2005;101:233-237.

25. Khanzadeh F, Khodaparast MH, Red AH, et al. Physiochemical properties of Gundelia tournefortii L. Seed oil. J Agr Sci Tech. 2012;14:15351542 .

26. Abdul DA, Hamd NS, Hassan HG. Characteristics of Fatty acids content in Gundelia L. oil extract. Iraqi National Journal of Chemistry. $2005 ; 45: 144-148$

27. Banu HR, Nagarajan N. GC-MS determination of bioactive components of Wedelia chinensis (Osbeck) Merrill. J Chem Pharm Res. 2013;5(4):279-285. 